\title{
Community concepts in plant ecology: from Humboldtian plant geography to the superorganism and beyond
}

\author{
M. Nicolson \\ Centre for the History of Medicine, School of Social and Political Sciences, \\ University of Glasgow, Glasgow, G12 8RT, UK \\ Correspondence to: M. Nicolson (malcolm.nicolson@glasgow.ac.uk)
}

Received: 12 March 2013 - Revised: 7 November 2013 - Accepted: 21 November 2013 - Published: 13 December 2013

\begin{abstract}
The paper seeks to provide an introduction to, and review of, the history of concepts of the plant community. Eighteenth-century naturalists recognised that vegetation was distributed geographically and that different species of plants and animals were interconnected in what would later be called ecological relationships. It was not, however, until the early nineteenth century that the study of vegetation became a distinctive and autonomous form of scientific inquiry. Humboldt was the first to call communities of plants "associations". His programme for the empirical study of plant communities was extended by many European and North American botanists, throughout the nineteenth and into the twentieth century. There developed an almost complete consensus among ecologists that vegetation was made up of natural communities, discrete entities with real boundaries. However, there was little agreement about the nature of the putative unit or how it should be classified. Gleason advanced the alternative view that vegetation was an assemblage of individual plants, with each species being distributed according to its own physiological requirements and competitive interactions. This debate was never wholly resolved and the divergent opinions can be discerned within early ecosystem theory.
\end{abstract}

\section{Introduction}

Vegetation has always been an important aspect of humanity's experience. We can assume that, from the earliest times, a coherent and communicable classification of plant cover was an essential aid to successful food gathering, hunting and the choosing of sites for agriculture. Words which identify features of the Earth's plant cover are in common use. Terms such as moor, heath, machair, tiaga, steppe, maquis, and many more, refer to familiar and apparently distinctive collective groupings of plants, to types of vegetation. It was not, however, until the early nineteenth century that plant communities became objects of scientific investigation. Alexander von Humboldt was the first explicitly to recommend to botanists the study of what he termed "socially organized plant life" (von Humboldt and Bonpland, 1807, p. 7 , 2009, p. 67). But on what sort of unit should the study of vegetation be based? How could it be characterised and distinguished from other groups? How extensive should it be?
These are issues that have occupied botanists and ecologists since vegetation first began to be studied systematically. This paper aims to provide a historical overview of the concept of the plant community, from its background before Humboldt, until the development of systems ecology in the latter half of the twentieth century.

\section{The eighteenth-century background}

Early in the 18th century, Richard Bradley, professor of botany at the University of Cambridge, noted that each species of insect tended to feed only upon a particular species of plant (Bradley, 1718, p. 3, 58-59; Egerton, 1973). Like many of his contemporaries, Bradley realised that different species of plants and animals were interconnected in what would later be called ecological relationships. Gilbert White's The Natural History of Selborne, published in 1789, is a classic expression of this recognition of the interdependence of species within the "oeconomy of nature" (White, 
1789). Similar ideas had, however, already been well developed in the earlier work of Carl Linnaeus (Egerton, 2007).

As a widely travelled, practical collector of plants, Linnaeus knew that plant species tended to grow in characteristic "stations", a concept broadly similar to the modern idea of "habitat" (Linnaeus, 1762; Limoges, 1972). He observed, moreover, that groups of different species tend to be found growing together in similar situations, as in his famous floristic characterisations of the bog and marsh vegetation of Scandinavia (Du Rietz, 1957). Linnaeus also described the zonation of vegetation around the shores of lakes, and noted how, over time, the plants of one zone replaced those of another. Both Linnaeus and Albrecht von Haller described the altitudinal zonation of vegetation on the slopes of mountains (Browne, 1983).

Eighteenth-century naturalists were, thus, well aware that vegetation was distributed geographically and that species were interdependent upon one another. Botanists frequently found it convenient to refer to vegetational features, employing layperson's terminology for this purpose. Such references were often quite specific. Linnaeus, for example, in his Philosophia Botanica of 1751 distinguished twenty-five different plant habitats and gave the genera characteristic of each one (Moss, 1910, p. 27). He was often very perceptive in his remarks on the distribution of vegetation. But all his observations on vegetation in this context were made as an adjunct to his concerns in plant collecting and systematics they were secondary to his floristic activities. Reference to vegetational features allowed him to specify more accurately the species he was describing and where it was to be found.

Around the turn of the eighteenth century, the German botanist Karl Ludwig Willdenow made observations of, and theorised about, the relationship between climate and the geography of plants $(1792,1805$, p. 337). His Principles of Botany contained much fine observation of vegetation. There was, for instance, a perceptive account of what was later to be termed "plant succession":

The decay of these mosses and smaller plants produces, by degrees, a thin stratum of earth, which increases with years, and now even allows some shrubs and trees to grow in it, till finally, after a long series of years, where once naked barren rocks stood, larger forests with their magnificent branches delight the wanderer's eye (Willdenow, 1805, p. 393-394).

Willdenow also described the corresponding successional process which begins with open water. But, like Linnaeus, Willdenow did not investigate vegetation for its own sake. His remarks on vegetational development, as on other vegetational matters, remained incidental to his floristic concerns.

\section{Alexander von Humboldt and the origins of vegetational geography}

However, it was the work of one of Willdenow's students that established the study of vegetation as a distinctive and autonomous form of scientific inquiry (Nicolson, 1987). In 1793, Alexander von Humboldt first set out the programme for a new form of plant geography, which was distinctively different from the floristic studies of the Linnean tradition. $\mathrm{He}$ argued that botanists should not confine themselves to the study of descriptive taxonomy and nomenclature, nor should they be preoccupied with the distribution of individual plant species. The central concern of the plant geographer should be, by contrast, the collective phenomena of vegetation:

Observation of individual parts of trees or grass is by no means to be considered plant geography; rather plant geography traces the connections and relations by which all plants are bound together among themselves, designates in what lands they are found, in what atmospheric conditions they live (von Humboldt, 1793, p. 9-10; Hartshorne, 1958, p. 100).

Fourteen years later, Humboldt published a fuller outline of the new plant geography, the Essai sur la géographie des plantes (von Humboldt and Bonpland, 1807, 2009). The Essai contains an elaborate engraving, entitled Tableau physique des Andes et pays voisins, which depicts a crosssectional profile of the Andes, from coast to coast. In this picture are mapped or tabulated: which plant and animal species live where, where the altitudinal zones of vegetation begin and end, the underlying geological structures, and physical or meteorological data. The object was to give, in a single illustration, a complete impression of a natural vegetational region - the "régions équinoctiales" of South America (Nicolson, 1996a).

The Tableau physique also represented more local differentiation. Within the "régions équinoctiales" were found, high on the mountains, a "région des lichens" and, lower down, a "région des Cinchona". These smaller sorts of vegetational region were characterised by physiognomic life forms, by the general appearance and habit of growth of the constituent plants. For example, "régions des lichens" were distinguishable by the obvious profusion of a number of species, all with the same lichenous life form. The study of plant physiognomy was an important feature of Humboldt's botanical enterprise and was one of the most decisive ways in which he departed from Linnaean taxonomic methods. Classification of vegetation by life form was essentially independent of floristic systems.

Humboldt's plant geography was a thoroughly empirical investigation of the environment of plants. A large number of instruments were used to measure a wide variety of physical parameters. The readings were tabulated, compared between different sites, and correlated with the occurrence of 
the various types of vegetation. It was hoped that such correlations would reveal the laws that governed the distribution of vegetation.

Humboldt was the first to call communities of plants "associations". He used the term informally: "The heaths, that association of erica vulgaris, of erica tetralix and the lichens icmadophilia and haemotomma" (von Humboldt and Bonpland, 1807 , p. 17, my translation). But it was not long before the term "association" became a technical one meaning a more or less definite plant community.

\section{Humboldtian plant geography in the nineteenth century}

The Danish botanist, Joachim Schouw, was one of the first to embrace Humboldt's programme for a vegetational plant geography. In 1823, he invented a nomenclature for associations, adding the suffix "-etum" to the generic name of the dominant plant. For example, "Fagetum" indicated a community dominated by a species of Fagus, the beech tree (Schouw, 1823, p. 165).

Another early exponent of Humboldtian plant geography was Franz Meyen, whose Grundriss der Pflanzengeographie appeared in 1836, with an English translation (Outline of the Geography of Plants) ten years later. Meyen made a sustained attempt to correlate the distribution of vegetation with physical variables, such as heat and moisture. Following Humboldt, one of Meyen's main concerns was the study of physiognomy, and his identification of vegetational units was based principally upon life form (Meyen, 1846).

The classification of vegetation according to physiognomy was further developed by August Grisebach, who introduced a new vegetational term, "formation":

I would term a group of plants which bears a definite physiognomic character, such as meadow ... a phytogeographic formation. The latter may be characterized by a single social species, by a complex of dominant species belonging to one family, or ... it may show an aggregate of species, which, although of various taxonomic character, have a common peculiarity; thus the alpine meadow consists almost exclusively of perennial herbs (Grisebach, 1838; Clements, 1916a, p. 116-117).

It became conventional to use the term "association", often with the "-etum" suffix, to refer to vegetation types characterised by floristic criteria, and the term 'formation' to refer to types characterised by physiognomy, as in Grisebach's examples. Grisebach's programme of research culminated with the publication, in 1872, of his monumental Die Vegetation der Erde nach Ihrer Klimatischen Anordnung (The Vegetation of the Earth according to its Climatic Arrangement), the first attempt to provide a comprehensive description and classification of the world's vegetation. Fifty-four physiognomic groups were recognised (Grisebach, 1872).
In the German-speaking countries, in France, and in Scandinavia, the Humboldtian style of vegetational plant geography was widely adopted (Nicolson, 1996b). Notable exponents were the Swiss botanists, Oswald Heer (1835) and Jules Thurmann. Thurman made a very clear distinction between the study of flora and the study of vegetation:

A region's flora is the enumeration and description of all the species growing there ... without reference to their abundance ... a region's vegetation is the plant life by which it is covered; it consists of the associated species of the flora in varying quantity and size, some playing a prominent role, others scattered and lost in the background ... A land's flora and its vegetation are two quite different things which should not be confused: the first means the numbers of the distinct plant species which one observes, the second their proportions and associations (Thurman, 1849, p. 22, my translation, emphasis in original).

In an important theoretical discussion, Henri Lecoq, Professor of Natural History at Clermont-Ferrand, clarified the distinction between "sociabilitie" - many plants of the same species living together - and "association" - many plants of different species living together (Lecoq, 1854, p. 58-90).

The Swedish botanist, Hampus von Post, and the Finn, Ragnar Hult, both applied the methods of Humboldtian plant geography to the vegetation of Northern Europe (Nicolson, 1996b). Von Post urged his fellow Scandinavian botanists to follow Humboldt and adopt a physiognomic approach to the investigation of "those associations of several plant species which together occupy a similar place ... on the earth's surface" (von Post, 1862). In his work on the vegetation of Sweden, von Post organised individual plots into associations and then classified these local associations into vegetationsgrupper, a category roughly corresponding in status to Grisebach's "formation", if smaller in size (Whittaker, 1962). Von Post also emphasised the importance of studying the interactions between the different species of plants within the association.

Like von Post, Hult developed a strictly physiognomic system in which both life forms and the vegetation units based upon them were narrowly defined. He argued that classification should be based solely upon the plant life forms and not upon features of the physical environment:

Because if one is to go ... to a moor in the middle of Finland, one can see there in an area, where no differences in the chemical or physical conditions can be shown, at least two sharply divided plant groupings alternating in patches. One is an even and dense mass of Clandina silvatica, with other lichens sprinkled in, as well as Polytricha and low Empetrum; the other is a similarly thick and even mat of Calluna vulgaris, with a sparse undergrowth of Cladonia, Hylcomia and Polytricha, as 
well as ... a few other plants. Here we can thus see an intimate mixture on the same location of two plant communities, which are in sharp contrast to each other (Hult, 1881, p. 9).

In these accounts of Nordic vegetation, we can discern emphases that were to become characteristic of the Uppsala school of phytosociology in the twentieth century - the recognition of relatively small vegetation units by physiognomic criteria and species composition rather than by environmental factors (Moss, 1910).

Thus, by the end of the nineteenth century, vegetation science was a flourishing enterprise and regional schools had begun to differentiate. In Southern Europe, the ZurichMontpellier style of plant geography was developed by Carl Schröter and Charles Flahault (Becking, 1957; BraunBlanquet, 1968). Schröter and his colleagues employed a concept of the plant community that was recognisable largely by floristic criteria. Schröter and Flahault's definition of the basic unit of vegetation was adopted by the International Botanical Congress in 1910:

An association is a plant community of definite floristic composition, presenting a uniform physiognomy and growing in uniform habitat conditions (Pavillard, 1935, p. 211).

The Swiss/French emphasis on floristic composition as the principal basis for the recognition of plant communities was further developed in the influential writings of Robert Gradmann (1909) and, especially, Josias BraunBlanquet. Braun-Blanquet's (1928) publication Pflanzensoziologie: Grundzüge der Vegetationskunde (translated into English in 1932 as Plant Sociology: The Study of Plant Communities) became regarded as the paradigmatic text of the floristic Zurich-Montpellier school of vegetation science (Van der Maarel, 1975).

One of the leading pioneers of German plant geography was Oscar Drude (1852-1933), who had worked with Grisebach and who continued his style of investigation. Like his mentor, Drude put a strong emphasis on the unitary integrity of the regional formation, the character of which was determined by the regional climate (Drude, 1896). Formations were, however, recognised as being internally heterogeneous due to the impact of topography and soil type upon the plant cover. Drude characterised the formation rather more floristically than Grisebach, recognising smaller subsidiary units, identifiable by locally dominant species.

The legacy of Grisebach's Die Vegetation der Erde stimulated many other botanists to study the relationship between vegetation and environment, notably Eugen Warming (Goodland, 1975; Coleman, 1986), whose major work Plantesamfund was published in Danish in 1895. An English translation, Oecology of Plants: An Introduction to the Study of Plant Communities, appeared in 1909. Warming defined the purpose of "Oecological plant-geography" as being to address three questions - "Why each species has its own special habitat? Why the species congregate to form definite communities? Why these have a characteristic physiognomy?" (Warming, 1909, p. 2-3). Warming sought to correlate the distribution of vegetation with climatic and other physical parameters, holding that physiognomic growth forms "stand in perfect harmony with the environment" and that "plants possess a peculiar inherent ... faculty by the exercise of which they directly adapt themselves" to their surroundings (Warming, 1909, p. 369-370). In other words, vegetation is the creation and the expression of the environment - a very Humboldtian conception.

Developments in morphology, evolution and physiology also impacted upon the subject, as exemplified by Andreas Schimper's major textbook of 1898, Pflanzengeographie auf Physiologischer Grundlage, translated into English in 1902 as Plant Geography upon a Physiological Basis. Schimper classified the world's vegetation into regions, formations and smaller units, and investigated the different forms of environmental interrelationships, drawing upon the developing understanding of plant physiology. Unlike Warming, Schimper was a strict Darwinian (Cittadino, 1990, p. 97-133), holding that the characteristics of each plant species were determined by the mechanism of natural selection.

\section{Divergent views - plant sociology, the superorganism, or the individualistic hypothesis}

Thus, by the beginning of the twentieth century, Humboldtian plant geography had been developed in a variety of ways in different parts of Europe. In some places, floristic composition was regarded as the most important feature by which plant communities were to be distinguished. Other schools made physiognomy central to their classification systems. In still other research programmes, greater weight was put upon the relation between the plant community and the physical environment, which could be conceived of in either Darwinian or Neo-Lamarckian ways. However, for most of the twentieth century there was an almost complete consensus among plant ecologists that vegetation was indeed made up of natural communities, recognisable, in principle, as discrete entities with real boundaries. These units were held to be part of the fabric of the natural world; they were not regarded as being the product of particular methods of classifying vegetation. The pre-eminent British ecologist, Arthur Tansley, succinctly outlined this research programme:

[I]f we admit, as everyone who has worked at the subject does admit, that vegetation forms natural units which have an individuality of their own and that these units owe their existence to the interaction of individual plants of different species with their environment, then it becomes clear that a mere study of the distribution of species as species cannot form the basis of the science of vegetation. We have instead to focus our attention on 
the vegetational units themselves (Tansley, 1920, p. 120-121).

Similar views were expressed in the United States, for instance by George Nichols, who defined the association as "a vegetation-unit characterised by its essentially constant physiognomy and by its essentially constant floristic composition" (Nichols, 1923, p. 17).

However, despite the fact that there was broad agreement as to the existence of natural units of vegetation, there was no consensus regarding the nature and extend of the putative unit or the exact basis on which it should be recognised. According to some schools, particularly in Western Europe, the vegetation unit was a small-scale, homogeneous community, whereas to most American ecologists, the association was a large-scale unit encompassing much local variation. Thus H. S. Conard, using the methods of European phytosociology, described 71 associations in central Long Island, whereas Clements recognised only three in the entire eastern deciduous forest of the USA (Conard, 1935; Weaver and Clements, 1938; McIntosh, 1958). The level of integration which pertained within the community, however characterised, was also a moot question.

In the early twentieth century, the study of the plant community developed rapidly in the United States. In 1898, Roscoe Pound and Frederic Clements produced The Phytogeography of Nebraska, which was explicitly modelled on Oscar Drude's Deutschlands Pflanzengeographie. Clements followed this with an impressive series of publications, culminating in 1916 with Plant Succession: An Analysis of the Development of Vegetation, which has been regarded as the paradigmatic presentation of the Clementsian system (Tobey, 1981).

To Clements, the primary unit of vegetation was the "formation", which was large in area, encompassing much variation and including several regional "associations". Formations were essentially physiognomic. Clements held, as a matter of definition, that the true dominants of any formation had all to be of the same life form, which was determined by the regional climate. The formation was, thus, defined as the "climax" community of an area over which the climate was effectively uniform.

Clements credited the plant formation with a very high degree of internal integration, describing the formation as a "complex-" or "super-organism".

The developmental study of vegetation necessarily rests upon the assumption that the unit or climax formation is an organic entity. As an organism, the formation arises, grows, matures and dies (Clements, 1916a, p. 3).

Individual stands of climax vegetation were considered to be the constituent parts of the formation as organism, presumably to be thought of as the equivalent of the tissues or cells of an individual, although Clements did not specify a pre- cise analogy. Stands of vegetation within the area of a formation but physiognomically distinct were said to be connected developmentally with the climax vegetation. These were the immature forms of the superorganism.

Thus, to Clements, whatever vegetation fell within an area of "effectively uniform" climate was, of necessity, all part of the formation characteristic of, and controlled by, that climate. The processes of vegetational succession, soil maturation and geomorphological base-levelling would, eventually, if the climate were to remain constant, allow all the vegetation growing with the geographical limits of the formation to develop into the highest form of vegetation possible under the given climate. Only a single vegetation type could be regarded as true climax within any given climate. This was the "monoclimax" theory.

In Plant Succession, Clements examined the effects of animals upon plant communities and began to suggest that a more complete understanding of the development of ecological phenomena would emerge if the study of natural communities encompassed animal populations:

No adequate treatment of this subject is possible, however, until the interaction of plant and animal communities at the present time is much better understood. Indeed, it seems certain that this will involve not only the articulation of distinct but associated plant and animal communities, but the recognition of actual biotic communities, in which certain plants and animals are at least as closely and definitely interdependent as the plants or animals are among themselves (Clements, 1916a, p. 319).

In the year that Plant Succession was published, Clements explicitly expanded the scope of his basic community concept. The principal unit of his ecological system became the "biotic community or biome", which comprised "all the species of plants and animals at home in a particular habitat" (Clements, 1916b, p. 120). To Clements, the biome formation was a highly organised entity with holist and emergent characteristics:

One of the first consequences of regarding succession as the key to vegetation was the realisation that the community ... is more that the sum of its individual parts, it is indeed an organism of a new order (Clements and Shelford, 1939, p. 21).

Clements supported this view of the plant community by claiming affinity for it with other holistic theorists, such as the philosopher and mathematician A. N. Whitehead, the entomologist, William Morton Wheeler, and J. C. Smuts, the author of Holism and Evolution (1926). There was a considerable vogue for holism in the United States at this time. Clements pointed, in particular, to the similarity between his conception of the plant community and the views of Herbert Spencer on the emergent properties of human societies 
(Clements, 1935, p. 35; Nicolson, 1989). By "emergent" properties was meant those features of the whole that were not predictable from the study of its parts.

In according a central importance to succession in the understanding of the plant community, Clements was influenced by the seminal studies of the sand dunes of Lake Michigan that Henry Cowles had undertaken around the turn of the century (Cowles, 1901). Cowles did not rival Clements as a prolific author, but his students, such as W. S. Cooper, dominated American ecology between the wars. Cooper accepted that plant communities were real entities, but did not endorse Clements' identification of them as highly integrated superorganisms (Cooper, 1926). He also differed from Clements in defending a polyclimax view, believing that some local associations, of non-climax life form, were effectively permanent, within any reasonable timescale. Cooper's view might be regarded as representative of the mainstream of ecological opinion in the United States and Great Britain. Nevertheless, he and most of his contemporaries agreed with Clements that plant communities were discrete, natural entities, the main issue of debate being the degree and extent of their internal integration.

There was one dissenting voice. Henry Gleason advanced what he called an "individualistic concept" of the plant association (Gleason, 1917, 1926, 1939; McIntosh, 1975; Nicolson, 1990; Nicolson and McIntosh, 2002; for an alternative perspective, Eliot, 2007, 2011). Gleason acknowledged that plant communities could be studied and mapped in the field and that their structure was the product of interaction between and among species. However, he denied that associations were highly integrated and that they were the fundamental units of vegetation. Gleason asserted that associations have no functional properties beyond the sum of the agencies and interactions of their constituent plants. Vegetation was an assemblage of individual plants, with each species being distributed according to its own physiological requirements and competitive interactions with other plants. Species composition varied constantly in time and continuously in space. The classification of vegetation was merely a matter of convenience.

\section{Ecosystem theory}

Gleason's thesis was influential among the pioneers of gradient analysis of the 1960s, such as John Curtis (1959; McIntosh, 1993; Nicolson, 2001) and Robert Whittaker (1951, 1953; Westman and Peet, 1982). However, ideas similar to Clements' concept of a high level of interspecific integration within the community unit may be discerned within early systems ecology (Hagen, 1992; Simberloff, 1980). Eugene Odum, for instance, emphasised that "unique principles ... emerge at the supra-individual levels or organisation" (Odum, 1977, p. 1289; Taylor, 1988) and that adjustment to the environment took place at the level of the ecosystem as a whole:

We theorized that new systems properties emerge in the course of ecological development, and that it is these properties that largely account for the species and growth form changes that occur ... [T] here is a holistic strategy for ecosystem development (Odum, 1977, p. 1290).

But these views were not universally accepted (McIntosh, 1980, p. 239-44). John Curtis, for instance, reacted strongly against the approach to ecological theory developed by Eugene Odum and his brother Howard: "Only by getting many people to see the weakness of the Odum techniques will this evangelistic school be restrained" (Curtis, 1961). Curtis particularly denigrated Howard Odum's assertion that the then current understanding of the tropical rain forest permitted it being represented as embodying a stable "steady state" (Curtis, 1961). Likewise the British ecologist, John Harper, "harked back to the 'individualistic' interpretation of vegetation" (Harper, 1977a, p. 146) and vigorously expressed his dissent from the homeostatic and maximal productivity theses of the system ecologists:

For a long time (and still in some quarters) the view has prevailed that the ecosystems of nature are too complex for understanding - that all we can do is to describe them - or to measure their function as if they were whole organisms. This was the view of some biochemists in the 30's about the structure of proteins yet great leaps of understanding were made by those who were prepared to simplify the complexity and, as an act of faith, assume that the complex whole is no more than the sum of the components and their interactions. The development of plant ecology into a predictive and rigid science depends on a similar willingness (Harper, 1977a, p. 154)

Harper, moreover, regarded the holism of systems ecology as incompatible with the Darwinian Synthesis.

A theory of natural selection that is based on the fitness of individuals leaves little room for the evolution of populations or species toward some optimum, such as better use of environmental resources, higher productivity per area of land, more stable ecosystems or even the view that plants in some way become more efficient than their ancestors (Harper, 1977b, p. 777).

And indeed, more recent studies have tended to emphasise that even complex ecosystems are characterised by instability and non-equilibrium conditions (Bocking, 2013).

One looks in vain for any consensus as to the essential characteristics of natural communities, or how best to classify them. As Robert Whittaker acknowledged, the roots of 
these controversies seem to lie too deep for scientific observation or experiment ever to wither them away:

The basis of understanding and judging classifications cannot be one of literal verisimilitude or fidelity to nature. Rather than this, one finds that classifications develop in accordance with whole systems of interbalanced ... judgements ... A classification must be viewed as a cultural product, understood in a context which includes both cultural values and ecological conditions, and judged in its functional relation to present understanding and practice (Whittaker, 1962, p. 123).

Acknowledgements. I am particularly grateful to Sigidur Oladottir, who rendered the work of the Nordic Humboldtians accessible to me. Thanks also to the reviewers of an earlier version of this essay.

Edited by: K. Jax

Reviewed by: F. N. Egerton and two anonymous referees

\section{References}

Becking, R. W.: The Zurich-Montpellier School of Phytosociology, Bot. Rev., 23, 411-488, 1957.

Bocking, S.: The ecosystem: research and practice in North America, Web Ecol., 13, 43-47, doi:10.5194/we-13-43-2013, 2013.

Bradley, R.: New Improvements of Planting and Gardening, both Philosophical and Practical, London, 3 Vols., 1718.

Braun-Blanquet, J.: Pflanzensoziologie: Grundzüge der Vegetationskunde, Berlin, Springer, 1928.

Braun-Blanquet, J.: Plant Sociology: The Study of Plant Communities, New York, McGraw-Hill, 1932.

Braun-Blanquet, J.: L'école phytosociologique zurichomontpelliéraine et la S.I.G.M.A., Vegetatio, 16, 1-78, 1968.

Browne, J.: The Secular Ark: Studies in the History of Biogeography, New Haven, Yale U.P., 1983.

Cittadino, E.: Nature as Laboratory: Darwinian Plant Ecology in the German Empire, 1880-1900, Cambridge, Cambridge U.P., 1990.

Clements, F. E.: Plant Succession: An Analysis of the Development of Vegetation, Washington, D.C., Carnegie Institute, 1916a.

Clements, F. E.: The Development and Structure of Biotic Communities, J. Ecol., 5, 12-21, 1916b.

Clements, F. E.: Social Origins and Processes among Plants, in: A Handbook of Social Psychology, edited by: Murchison, C. and Worcester, M. A., Clark University Press, 1935.

Clements, F. E. and Shelford, V. E.: Bioecology, New York, Wiley, 1939.

Coleman, W.: Evolution into Ecology? The Strategy of Warming's Ecological Plant Geography, J. Hist. Biol., 19, 181-196, 1986.

Conard, H. C.: Plant Associations of Central Long Island: A Study in Descriptive Phytosociology, Amer. Mid. Nat., 16, 433-516, 1935.

Cooper, W. S.: The Fundamentals of Vegetational Change, Ecology, 7, 391-413, 1926.
Cowles, H. C.: The Physiographic Ecology of Chicago and Vicinity: A Study of the Origin, Development and Classification of Plant Societies, Bot. Gaz., 31, 73-108, 145-182, 1901.

Curtis, J. T.: The Vegetation of Wisconsin: An Ordination of Plant Communities, Madison, University of Wisconsin Press, 1959.

Curtis, J. T.: Letter to H. J. Oosting, 10 February, 1961, Curtis Papers, University Archives, University of Wisconsin, Madison, 1961.

Drude, O.: Deutschlands Pflanzengeographie: Ein Geographisches Charakterbild der Flora von Deutschland und den Angrenzenden Alpen-sowie Karpathenländern, Stuttgart, Engelhorn, 1896.

Du Rietz, G. E.: Linnaeus as a Phytogeographer, Vegetatio, 5, 161168, 1957.

Egerton, F. N.: Changing Concepts of the Balance of Nature, Quart. Rev. Biol., 48, 322-350, 1973.

Egerton, F. N.: A History of the Ecological Sciences, Part 23: Linnaeus and the Economy of Nature, Bull. Ecol. Soc. Amer., 88, 72-88, 2007.

Eliot, C.: Method and Metaphysics in Clements's and Gleason's Ecological Explanations, Stud. Hist. Philos. Biol. Biomed. Sci., 38, 85-109, 2007.

Eliot, C.: The Legend of Order and Chaos: Communities and Early Community Ecology, in: Handbook of the Philosophy of Science 11: Philosophy of Ecology, edited by: de Laplante, K., Brown, B., and Peacock, K. A., Philadelphia, Elsevier, 49-107, 2011.

Gleason, H. A.: The Structure and Development of the Plant Association, Bull. Torrey Bot. Club, 43, 463-481, 1917.

Gleason, H. A.: The Individualistic Concept of the Plant Association, Bull. Torrey Bot. Club, 53, 7-26, 1926.

Gleason, H. A.: The Individualistic Concept of the Plant Association, Amer. Mid. Nat., 21, 92-111, 1939.

Goodland, R. J.: The Tropical Origin of Ecology: Eugen Warming's Jubilee, Oikos, 26, 240-245, 1975.

Gradmann, R.: Über Begriffsbildung in der Lehre von den Planzenformationen, Bot. Jahr., 43, 91-103, 1909.

Grisebach, A. H. R.: Über den Einfluss des Climas auf die Begränzung eer Natürlichen Floren, Linnaea, 12, 159-200, 1838.

Grisebach, A. H. R.: Die Vegetation der Erde nach ihrer Klimatischen Anordnung, Leipzig, Englemann, 1872.

Hagen, J. B.: An Entangled Bank: The Origins of Ecosystem Ecology, New Brunswick, Rutgers U.P., 1992.

Harper, J. L.: The Contributions of Terrestrial Plant Studies to the Development of the Theory of Ecology, in: Changing Scenes in the Life Sciences, 1776-1976, edited by: Goulden, C. E., Special Publ. 12, Acad. Nat. Sei. Phila., Penn., 139-157, 1977a.

Harper, J. L.: The Population Biology of Plants, New York, Academic Press, 1977b.

Hartshorne, R.: The Concept of Geography as a Science of Space, from Kant and Humboldt to Hettner, Annal. Assoc. Amer. Geog., 48, 97-108, 1958.

Heer, O.: Beitrage zur Pflanzengeographie, Zurich, Orelli, 1835.

Hult, R.: Försök till Analytisk Behandling av Växtformationerna, Societas pro Fauna et Flora Fennica Meddelanden, 8, 1-155, 1881.

Lecoq, H.: Etudes sur la Géographie Botanique de l'Europe, 9 Vols., 4, Paris, Baillière, 1854.

Linnaeus, C.: De Oeconomia Naturae, in: Miscellaneous Tracts relating to Natural History, Husbandry and Physick, edited by: Stillingfleet, B., 2nd Edn., London, 37-129, 1762. 
Limoges, C.: Charles Linné: L'équilibre de la Nature, Paris, Vrin, 1972.

McIntosh, R. P.: Plant Communities, Science, 128, 115-120, 1958.

McIntosh, R. P.: Henry Allan Gleason, individualistic ecologist 1882-1975, his contribution to ecological theory, Bull. Torrey Bot. Club, 102, 253-273, 1975.

McIntosh, R. P.: The Background and Some Current Problems of Theoretical Ecology, Synthese, 43, 195-255, 1980.

McIntosh, R. P.: The Continuum Continued: John T. Curtis's Influence on Ecology, in: Fifty Years of Wisconsin Plant Ecology, edited by: Fralish, J. S., Loucks, O. C., and McIntosh, R. P., Madison, Wisconsin Acad. Sci., 1993.

Meyen, F.: Outline of the Geography of Plants, London, Ray Society, 1846, reprinted by New York, Arno Press, 1977.

Moss, C. E.: The Fundamental Units of Vegetation, New Phytol., 9, 18-53, 1910.

Nichols, G. E.: A Working Basis for the Ecological Classification of Plant Communities, Ecology, 4, 11-23, 1923.

Nicolson, M.: Alexander von Humboldt, Humboldtian science, and the Origins of the Study of Vegetation, Hist. Sci., 25, 167-194, 1987.

Nicolson, M.: National Styles, Divergent Classifications: A Comparative Case Study from the History of French and American Plant Ecology, Knowledge and Society, 8, 139-186, 1989.

Nicolson, M.: Henry Allan Gleason and the Individualistic Hypothesis of the Plant Community: The Structure of a Botanist's Career, Bot. Rev., 56, 91-161, 1990.

Nicolson, M.: Alexander von Humboldt and the Geography of Vegetation, in: Romanticism and the Sciences, edited by: Jardine, N. and Cunningham, A., Cambridge, Cambridge U.P., 169-185, 1996a.

Nicolson, M.: Humboldtian Plant Geography after Humboldt: The Link to Ecology, Brit. J. Hist. Sci., 29, 289-310, 1996b.

Nicolson, M.: "Towards establishing ecology as a science instead of an art": the work of John T. Curtis on the plant community continuum, Web Ecol., 2, 1-6, doi:10.5194/we-2-1-2001, 2001.

Nicolson, M. and McIntosh, R. P.: H.A. Gleason and the Individualistic Hypothesis Revisited, Bull. Ecol. Soc. Amer., 83, 133-142, 2002.

Odum, E. P.: The Emergence of Ecology as a New Integrative Discipline, Science, 195, 1289-1293, 1977.

Pavillard, J.: The Present Status of the Plant Association, Bot. Rev., 1, 210-232, 1935.

Pound, R. and Clements, F. E.: The Phytogeography of Nebraska, North, Lincoln, 1898.

Schimper, A. F. W.: Pflanzengeographie auf Physiologischer Grundlage, Jena, Fischer, 1898.
Schouw, J. F.: Grundzüge einer Allgemeinen Pflanzengeographie, Berlin, Reimer, 1823.

Simberloff, D. S.: A Succession of Paradigms in Ecology, Essentialism to Materialism and Probabilism, Synthese, 42, 3-39, 1980.

Smuts, J. C.: Holism and Evolution, Macmillan, London, 1926.

Tansley, A. G.: The Classification of Vegetation and the Concept of Development, J. Ecol., 8, 118-148, 1920.

Taylor, P. J.: Technocratic Optimism, H. T. Odum, and the Partial Transformation of the Ecological Metaphor after World War II, J. Hist. Biol., 21, 213-244, 1988.

Thurman, J.: Essai de Phytostatique Appliqué a la Chaine du Jura et aus Contrées Voisines, Berne, 1849.

Tobey, R. C.: Saving the Prairies: The Life Cycle of the Founding School of American Plant Ecology, 1895-1955, Berkeley, University of California Press, 1981.

Van der Maarel, E.: The Braun-Blanquet Approach in Perspective, Vegetatio, 30, 213-219, 1975.

von Humboldt, A.: Flora Fribergensis Specimen, Berlin, 1793.

von Humboldt, A. and Bonpland, A.: Essai sur la Géographie des Plantes, Schoelle, Paris, 1807.

von Humboldt, A. and Bonpland, A.: Essay on the Geography of Plants, translated by: Romanowski, S., edited by: Jackson, S. T., Chicago, Chicago U.P., 2009.

von Post, H.: Försök till en Systematisk Uppställning af Vexställena i Mellersta Sverige, Stockholm, 1862.

Warming, E.: Plantesamfund: Grundtraek af den Økologiske Plantegeografi, Copenhagen, Philipsens, 1895.

Warming, E.: Oecology of Plants: An Introduction to the Study of Plant Communities, Oxford, Oxford U.P., 1909, reprinted by New York, Arno Press, 1977.

Weaver, J. E. and Clements, F. C.: Plant Ecology, 2nd Edn., New York, McGraw-Hill, 1938.

White, G.: The Natural History and Antiquities of Selborne, London, 1789.

Whittaker, R. H.: A Criticism of the Plant Association and Climatic Climax Concepts, Northwest Sci., 25, 17-31, 1951.

Whittaker, R. H.: A Consideration of Climax Theory: The Climax as Population and Pattern, Ecol. Monogr., 23, 41-78, 1953.

Whittaker, R. H.: Classification of Natural Communities, Bot. Rev., 28, 1-239, 1962, reprinted by New York, Arno Press, 1977.

Willdenow, K. L.: Grundriss der Kräuterkunde, Berlin, 1792.

Willdenow, K. L.: The Principles of Botany, and of Vegetable Physiology, Edinburgh, Blackwood, 1805.

Westman, W. E. and Peet, R. K.: Robert H. Whittaker (1920-1980): The Man and His Work, Vegetatio, 48, 98-122, 1982. 